\title{
KERAGAMAN JENIS KUPU-KUPU PADA WILAYAH DATARAN MASNI, KABUPATEN MANOWKARI
}

\section{(Butterfly Species Diversity in Masni Plain Area, District of Manokwari)}

\author{
Hasanudin Kelsubun ${ }^{1}$ dan Hermanus Warmetan ${ }^{1 凶}$ \\ Jurusan Kehutanan, Fakultas Kehutanan Universitas Papua Manokwari, Papua Barat, \\ 98314. Tlp/Fax: +62986211065. \\ ${ }^{\square}$ Penulis Korespondensi: Email: h_warmetan@yahoo.co.id \\ Diterima: 13 Mar 2019| Disetujui: 10 Apr 2019
}

\begin{abstract}
Abstrak
Penelitian ini bertujuan untuk mengetahui keanekaragaman jenis kupu-kupu yang tersebar pada wilayah dataran Masni, Kabupaten Manokwari. Dalam penelitian ini, metode yang digunakan yaitu deskriptif melalui kegiatan observasi lapangan secara langsung pada tiga bentang lahan yang berbeda yaitu pada tipe hutan sekunder, pada sisi aliran sungai, dan pada area pekarangan rumah. Hasil penelitian menunjukkan bahwa terdapat total 39 jenis kupu-kupu dari 5 famili dengan jumlah dominan berasal dari famili Nymphalidae dan yang paling sedikit ditemukan dari famili Papilionidae. Berdasarkan distribusinya, jumlah individu kupu-kupu yang paling banyak ditemukan pada area pekarangan dengan 304 individu. Namun dari hasil analisis indeks keragaman dan indeks kemerataan menunjukkan bahwa area hutan sekunder memiliki nilai indeks keragaman dan kemerataan tertinggi dengan nilai $H^{\prime}=3,54$ dan nilai indeks kemerataannya adalah 0,66 dibandingkan ke dua bentang lahan lainnya.

Kata kunci: kupu-kupu, hutan sekunder, area pekarangan, keragaman jenis, kemerataan jenis

Abstract

This study intends to perceive butterfly species diversity that spread over a plain area of Masni in Manokwari. Data were gathered by a direct field observation which carried out over three different landscapes such as secondary forest, riverbank, and homeyard area. These data then analyzed through descriptive method to acquire a detail understanding of the butterfly distribution. The result revealed that there was a total of 39 species of butterflies from 5 families with the most dominant family was Nymphalidae and the lest dominant was Papilionidae. In terms of distribution, the most butterflies have been found in the homeyard area with 304 individuals. However, species diversity and evenness species indices have indicated that the highest index was in the secondary forest compared to two other landscapes with the index score of $H^{\prime}=3.54$ and evenness index of 0.66 respectively. Keywords: butterfly, secondary forest, homeyard, species diversity, evenness species
\end{abstract}

\section{PENDAHULUAN}

Indonesia merupakan salah satu negara yang memiliki keanearagaman hayati tinggi. Indonesia dengan wilayah yang sangat luas, memiliki $10 \%$ flora bunga, $12 \%$ jenis mamalia, $17 \%$ jenis burung, 
$25 \%$ jenis ikan, dan $15 \%$ jenis serangga. Kekayaan dan keanekaragaman jenis yang tinggi tersebut, membuat Indonesia sering disebut dengan mega biodiversity (Endarwati 2005). Kupu-kupu merupakan salah satu komponen biotik pelengkap ekosistem yang mudah dikenali, karena terlihat menarik baik dari bentuk dan macam warna. Peran ekologi kupu-kupu dalam ekosistem tidak hanya sebagai herbivore semata, tetapi juga sebagai komponen yang penting dalam penyerbukan (Subahar et al. 2007).

Sumber daya alam merupakan anugera yang digunakan untuk memenuhi kebutuhan hidup. Sumber daya alam secara garis besar digolongkan menjadi sumber daya alam yang dapat diperbaharui dan sumberdaya alam yang tidak dapat diperbaharui serta tidak habis dipakai. Hutan merupakan salah satu sumber daya yang dapat diperbaharui, yang didalamnya terdapat berbagai jenis flora dan fauna (Furimbe 2014). Oleh sebab itu tidak mengherankan apabila hutan disebut sebagai tempat atau sumber kehidupan bagi manusia dan makhluk hidup lainnya.

Hutan di Papua termasuk dalam kelompok hutan yang sangat kaya akan keanekaragaman hayati baik flora maupun fauna, bahkan banyak diantara flora dan fauna tersebut yang merupakan jenis endemik Papua (Lekitoo et al. 2017). Serangga merupakan hewan yang sangat berperan dalam kehidupan manusia, baik dalam bidang pertanian, perdagangan, kedokteran, pendidikan, sebagai pengurai utama sisa-sisa organisme, bahan makanan, dan serangga juga memiliki nilai seni. Tetapi terdapat juga jenis serangga yang berbahaya atau sebagai perusak dalam kehidupan manusia. Salah satu jenis serangga yang berperan positif dalam kehidupan makhluk hidup adalah kupu-kupu.

Penyebaran kupu-kupu di Indonesia terbagi dalam dua region yaitu region Australia dan region Asia yang meliputi seluruh wilayah Indonesia kecuali kepulauan dan Papua (d'Abrera 1990). Lebih lanjut Person (1991), menyatakan bahwa Papua New Guinea yang berbatasan dengan Provinsi Papua (Irian Jaya) merupakan satu diantara daerah yang memiliki keragaman kupu-kupu tertinggi di dunia. Jika dibandingkan di daerah Eropa yang enam kali lebih luas dari New Guinea yang hanya memiliki 380 spesies, maka New Guinea dengan jumlah spesies 817 sangat kaya. Kondisi ini belum mencakup kajian menyeluruh spesies lain yang selama ini belum ditemukan.

Kupu-kupu termasuk salah satu satwa yang penting bagi dunia tumbuhtumbuhan, karena berperan membantu dalam proses penyerbukan sehingga secara tidak langsung ikut bertanggung jawab terhadap kelestarian lingkungan. Kupu-kupu juga merupakan jenis satwa liar yang memiliki nilai estetika karena daya tarik tersendiri baik dari bentuk fisik maupun kesan warna. Sehingga kupukupu banyak diminati banyak kolektor baik sebagai dasar seni dan pola. Bahkan sekarang ini kupu-kupu merupakan satwa yang memiliki nilai ekonomis karena telah di perdagangkan hingga ke manca negara.

Tingginya keanekaragaman kupu-kupu di papua menjadikan Papua sebagai daerah yang menarik untuk diteliti. Beranjak dari tingginya keanekaragaman kupu-kupu di wilayah Papua, maka penelitian ini bertujuan untuk mengetahui keanekaragaman kupu-kupu di Kampung Urey Distrik Masni Kabupaten 
Manokwari yang merupakan salah satu kawasan yang memiliki jenis kupu-kupu yang belum diketahui jenisnya. Sehingga, melalui penelitian ini dapat memberikan informasi dan pengetahuan terkait keragaman jenis kupu-kupu yang tentunya menambah khasan pengetahuan dari hutan tropis Papua.

\section{METODE PENELITIAN}

Penelitian ini dilaksanakan di Kampung Urey, Distrik Masni Kabupaten Manokwari dengan lamanya waktu penelitian \pm satu minggu pada bulan April tahun 2018. Yang menjadi obyek utama penelitian ini adalah jenis-jenis kupukupu yang tersebar pada Kawasan dataran hutan sekunder di wilayah Distrik Masni, Kampung Urey.

\section{Metode Penelitian}

Metode yang digunakan pada penelitian ini yaitu metode desriptif dengan teknik observasi lapang pada beberapa tipe lokasi antara lain di hutan tertutup, sekitar pinggir sungai dan areal pekarangan rumah penduduk.

\section{Variabel Pengamatan}

Variable penelitian ini terdiri dari variabel utama dan variabel pendukung. Variabel utama meliputi jenis-jenis kupukupu antara lain jenis, famili dan tipe kelamin dan proporsi jenis jenis individu dalam famili. Sementara variable penunjang yang dikumpulkan meliputi gambaran lokasi dan kondisi habitat kupu-kupu di Kampung Urey.

\section{Pengumpulan data}

Untuk memperoleh data jenis kupukupu di lokasi penelitian maka dilakukan pengamatan pada tiga lokasi yang berbeda yaitu pada areal hutan sekunder, pesisi sungai dan pekarangan yang dilakukan dengan berjalan mengikuti bentuk bentang lahan dan alur sungai. Untuk memperoleh kupu-kupu, dilakukan panangkapan dengan menggunakan wipping net dan diletakan pada steroform yang tersedia sebagai wadah specimen untuk selanjutnya diidenfitikasi dan dijadikan specimen koleksi. Untuk keperluan koleksi, kupu-kupu yang telah ditangkap selanjutnya dimasukan kedalam kertas kalkir yang telah dibentuk segi tiga dan diletakan ke dalam kotak yang tersedia dan diberi pengawet kapur barus. Dalam proses identifikasi, digunakan referensi buku panduan untuk membedakan jenis, famili dan tipe kelamin.

\section{Analisis data}

Data hasil penelitian berupa data jenis yang telah di kumpulkan dianalisis secara tabulasi dan disajikan dalam bentuk foto dan tabel. Selanjutnya nilai indeks keanekaragaman jenis kupu-kupu ditentukan dengan menggunakan indeks keanekaragaman Shannon-Wiener (Maguran 2004) dengan rumus :

$$
\mathrm{H}^{\prime}=-\sum_{\mathrm{i}=1}^{s} p \mathrm{~h} p, \mathrm{Pi}=\frac{\mathrm{n}}{\mathrm{N}}
$$

keterangan:

$\mathrm{Pi} \quad=$ Kelimpahan

$\mathrm{N}=$ Jumlah seluruh jenis kupu-kupu

$\mathrm{Ni}=$ Jumlah tiap jenis kupu-kupu

$\mathrm{H}^{\prime} \quad$ = Indeks Shannon-Wiener

Kemudian untuk mengetahui kesimbangan komunitas yakni ukuran kesamaaan jumlah individu antar spesies dalam dalam suatu komunitas, maka dilakukan analisis indeks kesamaan kemerataan (evenness index) dengan rumus : 
$E=\frac{H^{\prime}}{\operatorname{In}(S)}$

Dengan kisaran nilai sebagai berikut :

$\mathrm{e}<0,4 \quad$ : keseragaman populasi

kecil

$0,4<\mathrm{e}>0,6$ : keseragaman populasi

sedang

e $>0,6 \quad:$ keseragaman populasi

tinggi

Keterangan:

$\mathrm{H}^{\prime} \quad=$ indeks Shannon-Wiener

$\mathrm{S} \quad=$ jumlah jenis kupu-kupu

$\mathrm{E} \quad=$ indeks kemerataan (nilai antara 0-1).

\section{HASIL DAN PEMBAHASAN}

Jenis Kupu-Kupu

Berdasarkan hasil penelitian diketahui bahwa di kampung Urey Distrik Masni Kabupaten Manokwari memiliki keanekaragaman jenis kupu-kupu yang relatif cukup tinggi. Hasil penelitian menunjukkan bahwa terdapat 39 jenis kupu-kupu yang dari 5 famili dan sebagian besar ditemukan di areal pekarangan pemukiman. Dari total spesies kupu-kupu yang diperoleh, sebagian besar berasal dari famili Nymphalidae dan yang paling sedikit ditemukan berasal dari famili Papilionidae.

Berdasarkan grafik di atas dapat dilihat bahwa famili yang dominan adalah Nymphalidae dengan jumlah individu sebanyak 15 jenis, Pieridae sebanyak 11 jenis, Lycaenidae sebanyak 9 jenis, Hesperidae sebanyak 3 jenis dan yang paling sedikit adalah Papilonidae sebanyak 1 jenis. Ini menandakan bahwa keragaman jenis dan jumlah kupu-kupu cukup tinggi di kampung Urey Distrik Masni Kabupaten Manokwari.

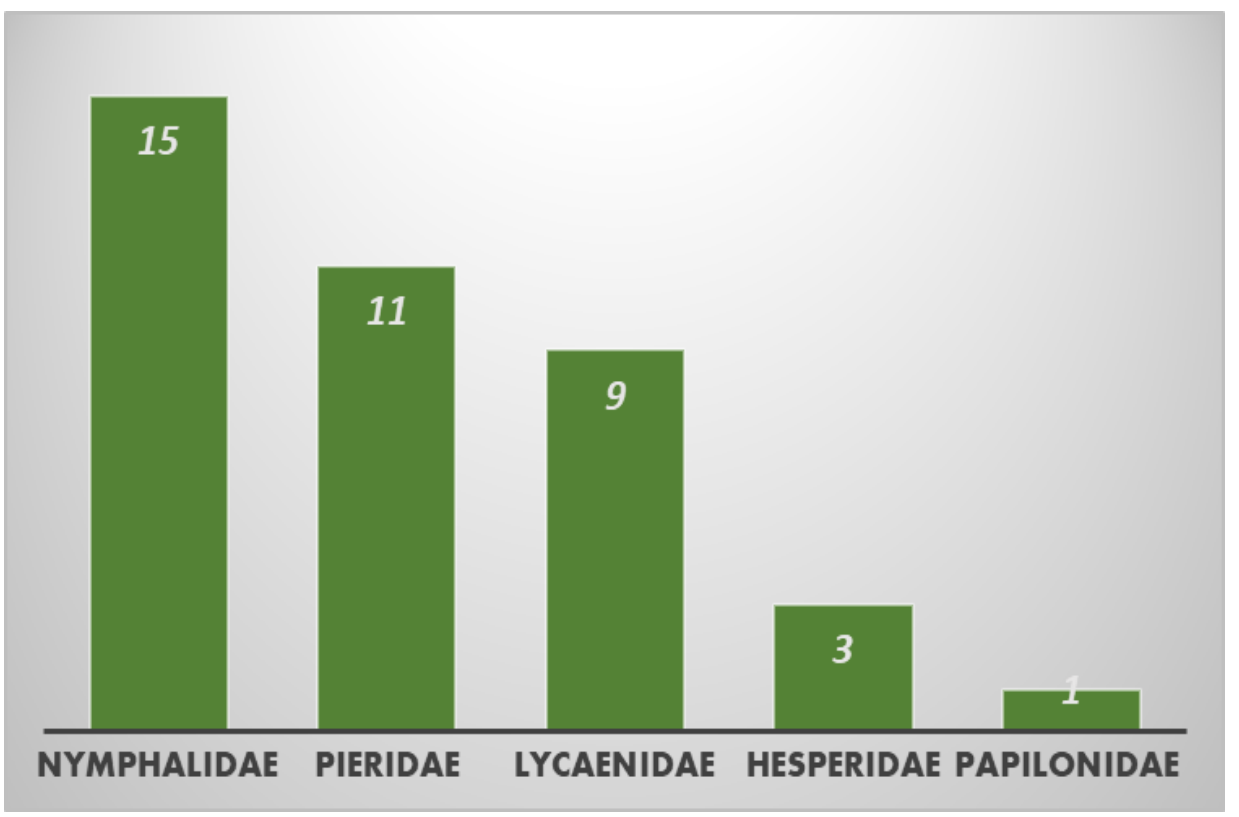

Gambar 1. Sebaran dan jumlah individu kupu-kupu berdasarkan famili yang ditemukan pada kawasan hutan sekunder Masni 


\section{Distribusi Berdasarkan Peruntukan Lahan}

\section{Hutan Sekunder}

Hutan sekunder adan hutan yang telah mengalami perubahan dari bentuk awalnya dengan adanya perubahan komposisi jenis dan bentang lahan secara signifikan (Corlett 1994). Dengan perubahan fungsi dan bentang lahan hutan, berdampak juga terhadap komposisi jenis flora dan fauna, termasuk jenis serangga dan kupu-kupu. Hutan di sekitar Kampung Urey merupakan hutan sekunder dari proses eksploitasi dan juga perkebunan rakyat yang dikelola oleh masyarakat lokal. Hadirnya komposisi jenis vegetasi hutan dan pertanian yang dikembangkan oleh masyarakat berpotensi mendatangkan jenis kupu-kupu pada kawasan hutan sekunder baik sebagai tempat mencari makan dan bermain. Dari hasil survei, ditemukan 137 individu kupu-kupu dari 5 famili dengan dominan famili adalah Nymphalidae. Sementara berdasarkan ser rasio, perbandingan jumlah jantan yang ditemukan sebanyak 26 jenis dan betina sebanyak 11 jenis.

\section{Sisi Sungai}

Aliran sungai memberikan dampak positif dengan adanya endapan nutrisi tanah yang penting bagi tumbuh dan berkembangnya jenis vehetasi hutan baik tumbuhan tingkat tinggi maupun tumbuhan tingkat rendah dengan ciri dan karakteri yang berbeda-beda. Hadirnya tipe vegetasi yang beragam pada sisi sungai memberikan tempat hidup dan berkembang berbagai organisme lain seperti kupu-kupu yang cenderung hadir pada tumbuhan yang berbunga. Dari hasil survei, diperoleh jumlah kupu-kupu sebanyak 216 individu dari 5 famili dimana famili yang dominan adalah Nimphalidae. Bila ditinjau dari perbandingan jenis kelamin, jumlah jantan ditemukan dengan jumlah yang lebih banyak yaitu 23 individu, sementara betina hanya sebanyak 7 individu.

\section{Area Pekarangan}

Hasil survei pada area pekarangan menunjukkan jumlah individu kupu-kupu sebanyak 304 dari 5 famili dengan dominasi famili adalah Nimphalidae. Secara keseluruhan dari ketiga bentang lahan, area pekarangan memiliki jumlah individu terbanyak dibandingkan kedua bentang lahan lainnya yakni hutan sekunder dan sisi sungai. Pekarangan menjadi pilihan dikarenakan jenis vegetasi yang ada adalah dominasi dari tumbuhan berbunga dengan variasi bunga dan aroma yang beragam. Dengan variasi jenis tumbuhan berbunga ini, tentu menjadi daya Tarik utama bagi kupukupu untuk hadir dan berinteraksi dengan tumbuhan tersebut. Hasil penelitian ini sejalan dengan yang diutarakan oleh Irni dkk. (2016), dimana ditemukan jumlah terbanyak individu kupu-kupu pada lokasi pemukiman yang secara langsung memiliki tumbuhan berbunga yang relatif banyak sebagai inang dan habitat bagi kupu-kupu.

\section{Keragaman Jenis}

Hasil analisis tingkat keragaman jenis kupu-kupu di Kampung Urey secara keseluruhan tergolong tinggi dengan ratarata nilai indeks keragaman untuk ketiga bentang lahan adalah, $H^{\prime}=3,50$. Secara rinci terlihat bahwa indeks keragaman tertinggi diperoleh pada bentang lahan hutan sekunder dengan nilai $H^{\prime}=3,54$, kemudian disusul pada sisi sungai dengan nilai indeks keragaman $H^{\prime}=3,48$ dan area pekarangan dengan nilai indeks 
keragaman $H^{\prime}=3,47$. Tingginya indeks keragaman pada hutan sekunder diduga karena potensi ketersediaan pakan yang melimpah dan habitat yang biak bagi perkembangan kupu-kupu. Habitat yang baik menjadi indikator penting bagi distribusi dan keberadaan individu kupukupu. Sementara untuk kedua bentang lahan lainnya diduga hanya sebagai tempat singgah dan bermain ketika waktu pagi dan sore hari.

Keragaman kupu-kupu dikampung Urey diduga di pengaruhi oleh iklim, pakan, predator dan pathogen. Fakta ini didukung oleh Andrewartha dan Birch (1954) dalam Tarumingkeng (1994) menyatakan bahwa faktor lingkungan yang mempengaruhi populasi adalah cuaca (iklim), faktor makanan, makhluk hidup lain dan patogen, serta tempat hidup. Lebih lanjut Sulthoni (1976) dalam Ramly (2004) mengemukakan bahwa setiap jenis satwa sangat tergantung pada komposisi faktor-faktor lingkungan yang ada dihabitat tersebut antara lain: substrat, vegetasi, air dan iklim, sehingga satwa tersebut dapat mempertahankan kelangsungan hidupnya dan tidak berpindah ke tempat lain. Kenekaragaman kupu-kupu akan tinggi bila waktu yang dibutuhkan dalam studi ini lebih lama sehingga dapat melakukan pengamatan pada cakupan wilayah yang lebih luas dengan waktu pengamatan lebih lama.

\section{Indeks Kemerataan (Evenness)}

Indeks kemerataan digunakan untuk mengetahui kesimbangan komunitas yakni ukuran kesamaaan jumlah individu antar spesies di dalam suatu komunitas dengan kisaran indeks evenness adalah e $<0,4$; kemerataan populasi kecil, $0,4<\mathrm{e}$ $>0,6$; kemerataan populasi sedang, dan e $>0,6 ;$ kemerataan populasi tinggi.
Semakin mirip jumlah individu antar spesies (semakin merata penyebarannya), maka semakin besar derajat keseimbangan. Dari hasil survei lapang dan analisis jenis kupu-kupu pada tiga bentang lahan, hutan sekunder, sisi sungai dan area pekarangan, di kampong Urey terlihat memiliki indeks kemerataan yang tinggi dengan nilai indeks rata-rata sebesar 0,66. Dari ketiga lokasi yang berbeda, terindikasi indeks kemerataan tertinggi berada pada bentang lahan hutan sekunder dengan nilai 0,72 , kemudian diikuti pada bentang lahan sisi sungai sebesar 0,64 dan area pekarangan dengan indeks keseragaman 0,61 .

\section{DAFTAR PUSTAKA}

Corlett RT. 1994. What is secondary forest? Short communication. Journal of Tropical Ecology, 10: 445-447.

D'Abrera B. 1990. Butterflies of the Autralian Region. Third (Revised) Edition Hill House. Melbourne and London.

Endarwati. 2005. Keanekaragaman hayati konservasinya di Indonesia. On line at http://endarwati.blogspot.com/2005/09 keanekaragaman-hayati-daankonservasi-html. (akses 23 April 2018).

Furimbe MM. 2014. Keragaman jenis kupu-kupu siang (Lepidoptera) pada hutan alam, hutan tanaman dan kebun hortikultura Universitas Papua, Manokwari. Skripsi Sarjana Kehutanan. (Tidak diterbitkan).

Irni J, Masy'ud B dan Haneda NF. 2016. Keanekaragaman jenis kupu-kupu berdasarkan tipe tutupan lahan di waktu aktifnya di kawasan penyangga Tangkahan Taman Nasional Gunung Leuser. Media Konservasi, Vol 21 (3): 225-232. 
Lekitoo K, Peday HFZ, Panambe N and Cabuy RL. 2017. Ecological and ethnobotanical facet of 'Kelapa Hutan' (Pandanus spp.) and perspectives towards its existence and benefit. International Journal of Botany, 13: 103-114.

Magurran AE. 1998. Ecologycal diversity and its measurement. New Jersey: Princeton University Press.

Person M. 1991. Butterflies conservation. Oxford University. Bogor.

Ramly M. 2004. Studi populasi rusa bawean (Axis kuhlii) pada habitat alaminya di kawasan Suaka Alam
Pulau Bawean dan Pulau Tanjung Cina. Thesis: Program Pasca Sarjana Universitas Gadjah Mada Yogyakarta. (Tidak dipublikasikan).

Subahar TS, Anzilni FA and Devi NC. 2007. Butterfly (Lepidopter: Rhopalocera) distribution alongan altitudinal gradient on Mount Tangkuban Perahu West Java, Indonesia. The Raffles Bulletin of Zoology, 55 (1): 175-178.

Tarumingkeng RC. 1994. Dinamika populasi: Kajian ekologi kuantitatif. Pustaka Sinar Harapan. Jakarta. 